Technical paper

\title{
Scale-up Research in a Dual Fluidized Bed Gasification Process
}

\author{
Miha Narobe, ${ }^{1 *}$ Janvit Golob, ${ }^{1}$ Jernej Mele, ${ }^{2}$ Mihael Sekavčnik, ${ }^{2}$ \\ Andrej Senegačnik ${ }^{2}$ and Dušan Klinar ${ }^{3}$ \\ ${ }^{1}$ Faculty of Chemistry and Chemical Technology, University of Ljubljana, Večna pot 113, 1000 Ljubljana, Slovenia \\ ${ }^{2}$ Faculty of Mechanical Engineering, University of Ljubljana, Aškerčeva cesta 6, 1000 Ljubljana, Slovenia \\ ${ }^{3}$ Faculty of Chemistry and Chemical Engineering, University of Maribor, Smetanova ulica 17, 2000 Maribor, Slovenia \\ * Corresponding author: E-mail: miha.narobe@ gmail.com \\ Tel.: +38612419 522, Fax: +38612419220
}

Received: 25-09-2014

Dedicated to the memory of Prof. Dr. Jurij V. Brenčič.

\begin{abstract}
A successful co-gasification of plastics and biomass was achieved in the $100 \mathrm{~kW}$ dual fluidized bed (DFB) gasification pilot plant. The results of a pilot plant experiment were used as a sound basis for scale-up prediction to $750 \mathrm{~kW}$ semiindustrial DFB plant. By an eightfold increase of mass and heat flows a rather simplified co-gasification process was predicted. Namely, the losses occurring in gasification plants are expected to be relatively smaller in larger plants. The effect of decreased losses was studied with an equilibrium model. Three different situations were simulated with the following fixed values of losses: $70 \mathrm{~kW}, 115 \mathrm{~kW}$ and $160 \mathrm{~kW}$. The model showed an increase in fuel conversion when losses were reduced.
\end{abstract}

Keywords: Gasification; Simulation; Dual fluidized bed reactor; Scale-up

\section{Introduction}

Gasification is a route of thermo-chemical conversion by which solid fuels (e.g. wood, straw, shredded plastics) are transformed to a gaseous fuel, i.e. product gas. With the change in state of matter, new possibilities of fuel use arise. ${ }^{1}$ Gaseous fuel of suitable quality can run gas engines and gas turbines. An application in a chemical synthesis (e.g. production of methanol, Fischer-Tropsch synthesis) is also possible, but acceptable levels of impurities in the gas are much lower in these cases. ${ }^{2}$

When biomass is used as a feedstock, the product gas is carbon-neutral. If any auxiliary fuel is required, rapeseed methyl ester (RME) represents a solution proven in practice. ${ }^{3}$ With the use of shredded plastics the product gas is no longer carbon neutral. However, some other benefits are present: less waste in the landfills and the consumption of fossil fuels is slowed down by using product gas as a partial or complete substitute.
Different feedstocks or a combination of these can be processed in gasification plants. By feeding the feedstocks to a gasifier from separate hoppers the suitability of different feedstock ratios can be assessed by simply changing the corresponding mass flows. ${ }^{4}$ In case of Slovenia which is a heavily forested country the wood pellets or wood chips can represent at least a part of the gasifier's fuel.

The quality of product gas is influenced by the gasifier's design and process parameters. There are three main types of gasifier: moving bed, fluidized bed and entrained flow reactor. ${ }^{2}$ There are also gasification processes in which the plasma technology is used. Fluidized bed gasification is a state-of-the-art technology, ${ }^{2}$ while dual fluidized bed system represents its further commercially successful development with new plants built in Austria, Germany and Sweden. ${ }^{5}$ A combination of DFB technology and Fischer-Tropsch synthesis yields a fuel that resembles current market fuels. The development of such techno- 
logies is meaningful as the reserves of crude oil, represented by reserves-to-production ratio, are only sufficient for the next 53 years. ${ }^{4}$ The price of goods will increase when they become rarer, making the alternatives affordable even before the fossil fuels are completely depleted.

The description of $100 \mathrm{~kW}$ dual fluidized bed gasification pilot plant is common in the literature. ${ }^{5,6,7}$ The plant consists of two reactors: one for gasification and one for combustion. The latter is also called riser. ${ }^{8}$ Net effect of reactions is endothermic in the gasification reactor and exothermic in the riser. Between the two vessels the heat is transferred by recirculating bed material, e.g. olivine. ${ }^{5}$ The bed material must be resistant to abrasion and preferably has a tar cracking activity. In the gasification reactor the fluidization is achieved with steam and the fuel particles are subject to drying, heating up, pyrolytic decomposition and gasification reactions. A part of char produced in the gasification reactor by fuel decomposition descends to the riser together with recirculating bed material. In the riser the fluidization is achieved with air and combustion takes place therein. An addition of fuel oil to the riser is necessary to keep up the operation in the $100 \mathrm{~kW}$ pilot plant.

By gasification of solid fuel with steam a product gas free of nitrogen can be produced without an investment in expensive air separation unit. ${ }^{2}$ The temperaturedependent equilibrium constraints exist in the gasification reactions. It can be deduced from the published results that water-gas shift (WGS) reaction is generally close to equilibrium. ${ }^{5,9}$

The basic criteria for experiment-based scale-up of $100 \mathrm{~kW}$ pilot plant to $750 \mathrm{~kW}$ semi-industrial plant are (i) similarity of residence times and temperatures in the gasification reactor and (ii) proportionality of mass and heat flows.

The steps of drying, heating up and pyrolytic decomposition have been studied by thermal gravimetric analysis (TGA). ${ }^{4}$ Based on the TGA measurements the decomposition time at any fixed temperature value can be mathematically predicted. ${ }^{10}$ This decomposition time can serve as a rough estimate of residence time.

Temperature is an important parameter that influences both reaction kinetics and equilibrium constants. ${ }^{2} \mathrm{Be}-$ sides, practical limitations to the choice of temperature are present: too low temperatures are not suitable because by them the tar content in product gas is increased, ${ }^{2}$ too high temperatures are not suitable because ashes must remain solid in the process.

The heat and mass flows are related. Eq. 1 was used in previous work ${ }^{4}$ to describe this correlation.

$$
P_{\mathrm{i}}=\left(L C V_{\mathrm{i}}+\left(h_{\mathrm{i}, T}-h_{\mathrm{i}, 298 \mathrm{~K}}\right)\right) m_{\mathrm{i}}
$$

The index $i$ in $E q .1$ refers to a flow, e.g. biomass. In the flows consisting of many chemical species, e.g. dry gas, the mass fractions of the involved compounds are used to calculate the average properties used in Eq. $1 .{ }^{4}$ The mass and heat balances can be joined in a mathematical model without an increase in the number of variables, when temperatures of the flows are measured. However, the losses are also included in the heat balance and must be estimated. They amount to $20 \mathrm{~kW}$ in the $100 \mathrm{~kW}$ pilot plant. ${ }^{4,7}$ In the larger plants the losses can be relatively smaller, when the plant is well constructed: good insulation and low surface-area-to-volume ratio are prerequisites. ${ }^{6}$ The surface-area-to-volume ratio is itself in relation to the fuel power size of the plant. It was estimated in the study ${ }^{11}$ that the losses in an industrial 10 MW DFB gasification plant would amount to $5 \%$ of fuel power.

The efficiency of the plant can be evaluated by comparing the lower calorific value of cold dry gas to lower calorific value of input (biomass, plastics or any other feedstock). The fuel oil added to the riser is also present in the cold-gas efficiency (CGE) calculation. ${ }^{12}$ Its addition influences the CGE in a negative way, as can be deduced from $E q .2$.

$$
\begin{aligned}
& \mathrm{CGE}=\left(m_{\mathrm{DG}} \cdot L C V_{\mathrm{DG}}-m_{\mathrm{O}} \cdot L C V_{\mathrm{O}}\right) / \\
& \left(m_{\mathrm{P}} \cdot L C V_{P}+m_{\mathrm{B}} \cdot L C V_{\mathrm{B}}\right)
\end{aligned}
$$

In a design of industrial plant the equilibrium model can be helpful, see the literature ${ }^{11}$ for an example of 10 MW DFB plant. Advantage of mathematical modeling over experimental work is that mathematical simulations are cheaper than experiments and enable easy changes of parameters. ${ }^{13}$ However, experimental work in which credible information regarding the performance of both plants was gathered still represents a foundation.

The aim of the current work is to predict the basic operating conditions of the plastics and biomass co-gasification in $750 \mathrm{~kW}$ semi-industrial plant. This plant has been used in biomass gasification experiments with limited success. Helpful data for process design shall be obtained from two major sources: (i) the successful co-gasification experiment in the $100 \mathrm{~kW}$ pilot plant and (ii) mathematical manipulation of the equilibrium model. The scale-up predictions shall represent usable contribution to the future operation of semi-industrial plant.

\section{Experimental}

Two materials were used in the experiments: wood pellets and shredded polyethylene plastics, from here on called "biomass" and "plastics" respectively. Three kinds of experiments related to current work were conducted: TGA analysis of mixed plastics-biomass samples for prediction of decomposition times, $100 \mathrm{~kW}$ pilot plant experiments in which biomass and plastics were co-gasified and $750 \mathrm{~kW}$ experiment with biomass as feedstock.

The TGA experiments are described in previous work, ${ }^{4}$ while the description of isoconversional method 
commonly used for prediction of polymer decomposition times can be found in the paper. ${ }^{10}$

The co-gasification experiments in pilot plant are found described in detail in the literature. ${ }^{4}$ Of the pilot plant experiments there, only one was chosen as basis for scale-up procedure. Short description of the experiment is provided: the biomass and plastics were put in two separate hoppers. In the experiment the fuel power was decided to be $90 \mathrm{~kW}$, of which $75 \%$ was provided by plastics and $25 \%$ by biomass. LCV and elemental composition of both fuels were experimentally assessed. The mass of recirculating bed material amounted to $100 \mathrm{~kg}$. The temperature in the gasification reactor was kept at $850{ }^{\circ} \mathrm{C}$. The mass flows were $5.6 \mathrm{~kg} / \mathrm{h}$ for plastics, 4.6 $\mathrm{kg} / \mathrm{h}$ for biomass, $16.1 \mathrm{~kg} / \mathrm{h}$ for steam, $5.9 \mathrm{~kg} / \mathrm{h}$ for air 1 and $62.7 \mathrm{~kg} / \mathrm{h}$ for air 2. For a depiction of DFB system and its flows see Fig. 1. Important measurements included the dry gas composition, tar, dust and entrained char concentrations in product gas. Detailed description of measuring equipment is found in the literature. ${ }^{5}$ The suitable mass flow of fuel oil into the riser was also determined in the experiment.

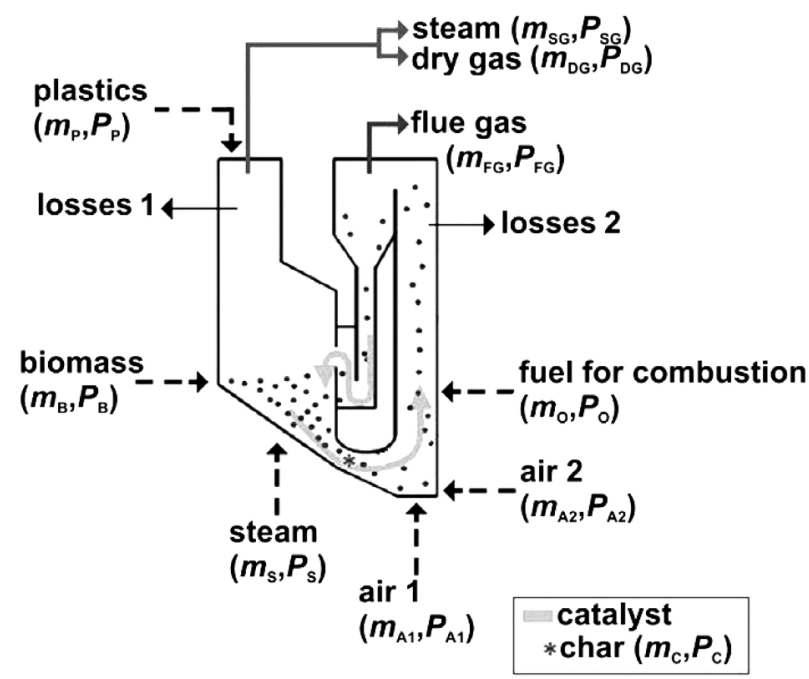

Fig. 1. Schematic representation of mass and heat flows. Losses of gasification reactor (losses 1) and losses of riser (losses 2) are presented separately in this figure. Their sum represents the losses of plant. Original image is found in the literature. ${ }^{4}$

In the biomass gasification experiment in $750 \mathrm{~kW}$ DFB plant a limited amount of data was collected, because the plant lacked the online dry gas analyzer. Experiments were conducted with biomass as fuel and steam as fluidization agent. The temperature of gasification reactor was $780{ }^{\circ} \mathrm{C}$. Mass flows were $180 \mathrm{~kg} / \mathrm{h}$ for biomass and $125 \mathrm{~kg} / \mathrm{h}$ for steam. The product gas was sampled during the plant operation and analyzed later in the laboratory. The usual number of samples taken in an experiment was four. Flue gas composition has been assessed to the extent required by Slovenian legislation.

\section{Modeling}

In this section the basic equations are provided for easier description and understanding of the model results. The model ${ }^{4}$ is based on three elemental mass balances and one heat balance. The basic model is used for calculation of missing flows from the experimental results, while its upgrade is used to predict the equilibrium composition of product gas.

Firstly, the basic model is presented together with its equations for calculation of missing flows from experimental results. The elemental mass balances of carbon, oxygen and hydrogen for gasification reactor are very similar to each other. In the model they are used in following forms:

$$
\begin{aligned}
& f_{\text {carbon }}=\left(\left(m_{\text {carbon,in }}-m_{\text {carbon,out }}\right) / m_{\text {carbon,in }}\right)^{2} \\
& f_{\text {hydrogen }}=\left(\left(m_{\text {hydrogen,in }}-m_{\text {hydrogen,out }}\right) / m_{\text {hydrogen,in }}\right)^{2} \\
& f_{\text {oxygen }}=\left(\left(m_{\text {oxygen,in }}-m_{\text {oxygen,out }}\right) / m_{\text {oxygen,in }}\right)^{2}
\end{aligned}
$$

In case of experiments the compositions of all flows concerned in the elemental mass balances of gasification reactor are known or assumed. The composition of biomass, plastics and dry gas is experimentally assessed. Char flow is assumed to be $100 \%$ carbon. Thus, there are only two unknown variables in these elemental mass balances: the mass flow rates of char and steam out of gasification reactor $\left(m_{\mathrm{C}}, m_{\mathrm{SG}}\right)$.

The heat balance for the whole system is:

$$
\begin{aligned}
& f_{\text {heat }}=\left(\left(P_{\mathrm{L}}+P_{\mathrm{DG}}+P_{\mathrm{FG}}+P_{\mathrm{SG}}\right) /\right. \\
& \left.\left(P_{\mathrm{A} 1}+P_{\mathrm{A} 2}+P_{\mathrm{B}}+P_{\mathrm{O}}+P_{\mathrm{P}}+P_{\mathrm{S}}\right)-1\right)^{2}
\end{aligned}
$$

With introduction of heat balance no new variable is added. As already explained in the section Introduction, the heat flows are related to mass flows $(E q .1)$. The losses of DFB plant, designated as $P_{\mathrm{L}}$ in $E q$. 4, are usually known before the calculation, e.g. $20 \mathrm{~kW}$ in $100 \mathrm{~kW}$ pilot plant. ${ }^{4}$ The mass flow of fuel oil is measured in the experiment. Thus, a minimization of the function $f_{\text {total }}$ is required, by which the two unknown variables are found.

$$
f_{\text {total }}=f_{\text {heat }}+f_{\text {carbon }}+f_{\text {hydrogen }}+f_{\text {oxygen }}
$$

In the case of equilibrium predictions, all the equations presented above (Eq. 3-5) still apply. The difference is however that the fractions of chemical species in dry gas are seen as variables. The dry gas is assumed to consist of three species only: carbon monoxide, carbon dioxide and hydrogen. By this assumption the fractions of hydrocarbons are no longer present in the calculation. In heat balance the mass flow of fuel oil is not a measured value, but is instead correlated to mass flow of char $\left(m_{\mathrm{C}}\right)$ by assuming $\lambda=1$ in the riser. The number of variables in 
calculation is further reduced by applying the correlations:

$$
\begin{aligned}
& y_{\mathrm{H} 2}+y_{\mathrm{CO} 2}+y_{\mathrm{CO}}=1 \\
& y_{\mathrm{H} 2, \mathrm{PG}} \cdot y_{\mathrm{CO} 2, \mathrm{PG}} /\left(y_{\mathrm{H} 2 \mathrm{O}, \mathrm{PG}} \cdot y_{\mathrm{CO}, \mathrm{PG}}\right)=0.9
\end{aligned}
$$

Results obtained by the minimization of the function $f_{\text {total }}(E q .5)$ in case of equilibrium model are in the form of the triplet $\left(y_{\mathrm{H} 2}, m_{\mathrm{C}}, m_{\mathrm{SG}}\right)$. The losses are a parameter, the value of which is chosen before the minimization. In literature the equilibrium methane content was calculated to be close to nought. ${ }^{11,14}$ The aforementioned assumption of only three species in dry gas, which also means zero methane content in dry gas, thus appears acceptable. Equilibrium predictions share some basic data with the experiments, e.g. mass inflows and the measured temperatures. ${ }^{4}$

Two noteworthy modifications were introduced in the above presented model and its upgrade to make them usable in scale-up. Firstly, the input data was modified to account for larger plant. Basic mass and volume flows encountered in the pilot plant experiment (biomass, plastics, steam, air 1 and air 2) were increased eightfold, while the temperatures and compositions of these flows remained the same. Secondly, in equilibrium calculation the alternative values of losses not stemming from an experimental background were used in the heat balance. The chosen values of this parameter were $70 \mathrm{~kW}, 115 \mathrm{~kW}$ and $160 \mathrm{~kW}$. The lowest value is roughly equal to $10 \%$ of fuel power, which seems a reasonable lower limit, taking aforementioned values of $20 \%$ for $100 \mathrm{~kW}$ pilot plant and $5 \%$ for $10 \mathrm{MW}$ plant in consideration. The model is written in Wolfram Mathematica software. Detailed presentation of original equations and supplementary data is found in the literature. $^{4}$

Table 1. Basic composition of the feedstocks as used in the model. ${ }^{4}$

\begin{tabular}{lcc}
\hline & Plastics & Biomass \\
\hline Lower calorific value $(\mathrm{MJ} / \mathrm{kg})$ & 43.270 & 17.458 \\
Water $\left(\%_{\text {wt. }}\right)$ & 0.00 & 6.11 \\
$\mathrm{C}\left(\%_{\text {wt., dry }}\right)$ & 87.09 & 50.23 \\
$\mathrm{H}\left(\%_{\text {wt. dry }}\right)$ & 12.42 & 6.04 \\
$\mathrm{O}\left(\%_{\text {wt., dry }}\right)$ & 0.00 & 43.38 \\
\hline
\end{tabular}

\section{Results and Discussion}

\section{1. TGA}

The residence time is of significant importance in chemical kinetics, but bears little significance for the steady-state predictions. In short, the decomposition time of mixed plastics-biomass samples was estimated based on TGA and Vyazovkin's formulae to be 2.5-6 minutes at $850{ }^{\circ} \mathrm{C}$, depending on the particle size of the biomass. ${ }^{4} \mathrm{It}$ is mentioned here to shed light on a general scope of the gasification process.

\section{2. Pilot plant}

The feasibility of biomass and plastics co-gasification in DFB plant was proven by the co-gasification experiments in $100 \mathrm{~kW}$ pilot plant. Many valuable experimental results were collected in the pilot plant run, e.g. dry gas composition and content of undesirable compounds in product gas. In fact, these were the most complete data at disposal for a scale-up procedure.

Table 2: Composition of dry product gas in the pilot plant experi-

\begin{tabular}{|c|c|}
\hline & $75 \%$ plastics, $25 \%$ biomass \\
\hline $\mathrm{H}_{2}\left(\%_{\text {vol,dry }}\right)$ & 49.5 \\
\hline $\mathrm{CO}\left(\%_{\text {vol,dry }}\right)$ & 24.1 \\
\hline $\mathrm{CO}_{2}(\%$ vol,dry $)$ & 8.4 \\
\hline Hydrocarbons $\left(\%_{\text {vol,dry }}\right)$ & 17.9 \\
\hline $\mathrm{LCV}_{\text {dry gas }}\left(\mathrm{MJ} / \mathrm{Nm}^{3}\right)$ & 16.0 \\
\hline
\end{tabular}
ment ( $75 \%$ plastics, $25 \%$ biomass). ${ }^{4,6}$

The experimentally assessed composition of dry gas is presented in Table 2. It can be compared to results of biomass mono-gasification, ${ }^{9}$ which represents a referential case for the $100 \mathrm{~kW}$ pilot plant. The hydrogen fraction is approximately $10 \%$ higher and carbon dioxide fraction is approximately $10 \%$ lower than in biomass gasification in the same plant. Fraction of carbon monoxide is quite similar to the one found in biomass gasification, while the content of hydrocarbons is slightly higher. The fraction of methane in dry gas was $12.7 \%_{\text {vol,dry }}$, which is slightly more than in case of biomass gasification. See the literature for dry gas compositions usually achieved with biomass feedstock in DFB plants. ${ }^{9}$ The product gas composition of the co-gasification experiment is relatively close to WGS equilibrium. ${ }^{15}$

In the experiment the smooth operation was achieved and the levels of undesirable compounds in product gas were low. The content of GC-MS tars measured in a one day long co-gasification experiment amounted to 8.2 $\mathrm{g} / \mathrm{Nm}^{3}{ }_{\text {dry gas }}$, while this content is $6 \mathrm{~g} / \mathrm{Nm}^{3}{ }_{\text {dry gas }}$ in an equally short biomass gasification experiment. In a prolonged experiment a decreased production of tars is expected..$^{5,16}$ In industrial plant the product gas from biomass gasification is cleaned further by scrubbing it with RME. ${ }^{3}$ With this procedure it becomes clean enough to be used in gas engines. The gas cleaning was not applied in case of $100 \mathrm{~kW}$ pilot plant. Instead, a product gas was analysed and combusted, as no further use of it was planned. An acceptable tar load for gas engines is $0.1 \mathrm{~g} / \mathrm{Nm}^{3}$ dry gas. ${ }^{2}$ It is plausible to assume that a combination of prolonged cogasification of biomass and plastics combined with RME scrubbing of product gas would reduce the tar content in the gas to acceptable levels for a gas engine use. 
During experiment the temperatures at various points of DFB reactor were measured. The temperatures were $850{ }^{\circ} \mathrm{C}$ for gasification reactor and $939{ }^{\circ} \mathrm{C}$ for the riser. Steam entered the gasification reactor with temperature of $311{ }^{\circ} \mathrm{C}$. The temperatures of air 1 and air 2 were $49{ }^{\circ} \mathrm{C}$ and $367{ }^{\circ} \mathrm{C}$ respectively. Known values of temperatures are prerequisite for calculation of heat flows, which are presented together with mass flows in the literature. $^{4}$

\section{3. Semi-industrial Plant}

Biomass gasification experiments have been conducted in $750 \mathrm{~kW}$ semi-industrial plant and the results of product gas analysis are presented in Table 3. The four product gas samples listed in the table all stem from the same experiment but were taken at different times during the stable operation of biomass gasification. During startup and shut-down phases no product gas was sampled. Each sample represents a product gas as it was produced at the moment of sampling. From the results presented in Table 3 it can be concluded that the process was quite stable throughout and without large variations in quality of product gas. In third sample the hydrogen content was the highest with a value of $28.1 \%_{\text {vol,dry }}$. In other samples, hydrogen content was in the range of $21.0-22.7 \%_{\text {vol,dry }}$. However, the carbon monoxide content was the lowest in third sample, with value of $39.1 \%$ vol,dry Other samples had a carbon monoxide content in the range of $42.1-45.3 \%$ vol,dry . The content of carbon dioxide was approximately $20 \%_{\text {vol,dry }}$ throughout the stable operation. Consistency of dry gas composition is not a surprise, since experiment was conducted at constant operating conditions as described in the experimental section. The low water content in fourth sample was not expected.

The results presented in Table 3 should be compared to biomass gasification results achieved in plants of comparable design but different size. These results are encountered in the literature. ${ }^{9}$ The comparison reveals similarity of the product gas water content, which is in the range of $30-45 \%_{\text {vol }}$ for DFB plants. ${ }^{9}$ However, the dry gas contents differ: the carbon monoxide fraction in semi-industrial plant experiments is approximately $20 \%$ higher and hydrogen fraction is approximately $20 \%$ lower than in case of biomass gasification in $100 \mathrm{~kW}$ pilot plant. ${ }^{9}$ Interestingly, the carbon dioxide content is almost equal in both cases. The methane content in Table 3 is slightly lo- wer than expected in DFB biomass gasification, while ethylene content is doubled compared to the literature data. ${ }^{9}$ The sum of methane and ethylene, however, appears to be similar in both cases. As both cases represent the DFB technology, with steam as gasification agent and biomass as fuel, a similarity of results was expected, but the measured values show that this does not apply.

After the results of the scale-up predictions were considered, it was deduced from the design of the $750 \mathrm{~kW}$ semi-industrial plant that the amount of heat transported to gasification reactor is quite low, i.e. the riser of semi-industrial plant seems to be undersized. Also, in some parts of the loop the air was used to achieve fluidization during the experiment, ${ }^{17}$ which is a design feature that may require a change in the future.

Small fraction $(<2 \%$ vol $)$ of oxygen was found in product gas, thus it is likely that oxygen in air, which entered the semi-industrial plant as fluidization agent, contributed

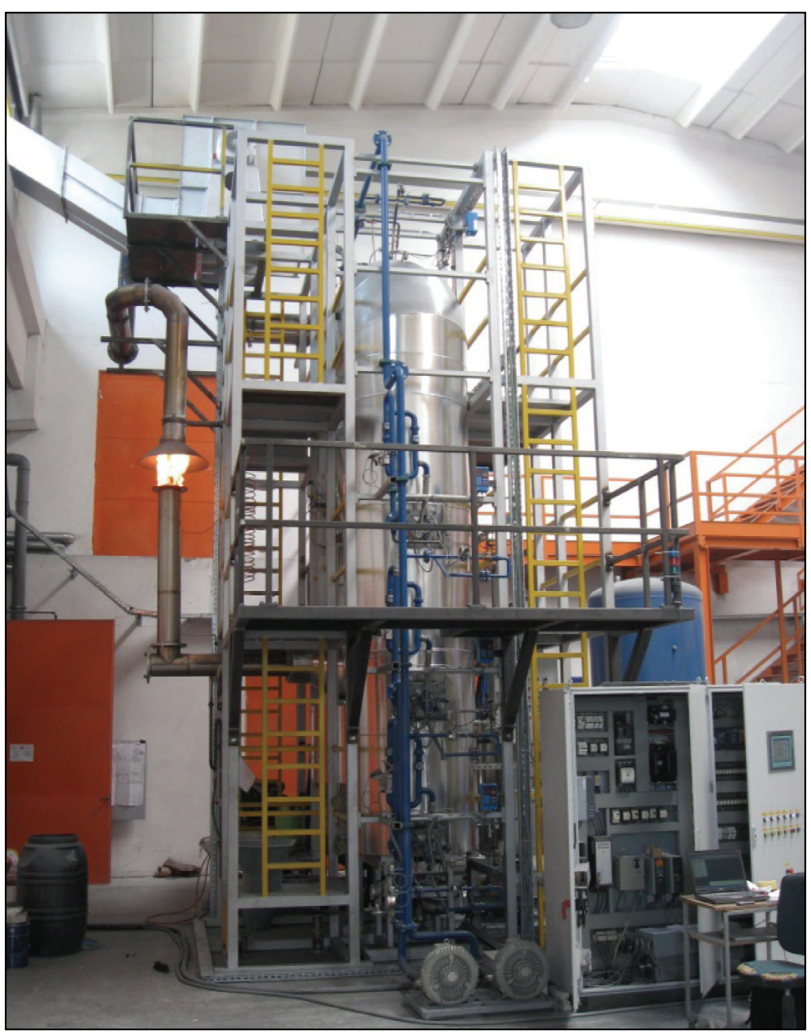

Fig. 2. The $750 \mathrm{~kW}$ semi-industrial plant. Photo courtesy of Bosio d.o.o. Author: Jernej Mele. ${ }^{17}$

Table 3. Composition of product gas in the semi-industrial $750 \mathrm{~kW}$ plant. Samples refer to the same experiment.

\begin{tabular}{lcccccc}
\hline & $\mathbf{H}_{\mathbf{2}}\left(\boldsymbol{\%}_{\text {vol,dry }}\right)$ & $\mathbf{C O}\left(\%_{\text {vol,dry }}\right)$ & $\mathbf{C O}_{\mathbf{2}}\left(\boldsymbol{\%}_{\text {vol,dry }}\right)$ & $\mathbf{C H}_{\mathbf{4}}\left(\boldsymbol{\%}_{\text {vol,dry }}\right)$ & $\mathbf{C}_{2} \mathbf{H}_{\mathbf{4}}\left(\boldsymbol{\%}_{\text {vol,dry }}\right)$ & $\mathbf{H}_{\mathbf{2}} \mathbf{O}\left(\%_{\text {vol }}\right)$ \\
\hline Sample 1 & 21.0 & 45.3 & 21.5 & 7.5 & 3.9 & 38 \\
Sample 2 & 22.7 & 42.1 & 20.3 & 8.9 & 4.7 & 43 \\
Sample 3 & 28.1 & 39.1 & 18.8 & 8.3 & 4.3 & 43 \\
Sample 4 & 21.0 & 45.2 & 21.1 & 7.9 & 4.2 & 25 \\
\hline
\end{tabular}


to the formation of carbon monoxide. With measuring equipment for nitrogen this assumption could have been confirmed.

However, even from the presentation of a basic product gas analysis it becomes clear that the plant does not achieve similar results as those of Austrian make. Certain changes in design are required to improve the results of the plant. It is common that a plant's design improves over time. Two improvements suggested from the model predictions are to increase heat production in the riser and to increase the circulation rate of the bed material between the reactors. Some faults in plant design can be identified only with experimental work, which in case of the semiindustrial plant is quite expensive due to the plant's size. The goal of all the improvements is to achieve the results which would be comparable to those of similar plants in product gas quality and smoothness of operation, making the plant also commercially interesting.

\section{4. Scale-up Predictions}

In current work the four scale-up predictions are discussed. The first scale-up prediction is based on the pilot plant experiment in which $75 \%$ of fuel power is covered by plastics and $25 \%$ by biomass. The fuel power in original pilot plant experiment amounted to $90 \mathrm{~kW}$. When the mass and heat flows of the pilot plant experiment are increased eightfold the scale-up procedure results in a 720 kW process as seen in Fig. 3. Small discrepancy between the prediction and the nominal fuel power of the semi-industrial plant $(750 \mathrm{~kW})$ is not problematic, as discrepancies are also encountered in the experiments, i.e. feedstock heat flows of $90 \mathrm{~kW}$ in a $100 \mathrm{~kW}$ pilot plant. ${ }^{4}$ The losses in the experiment-based scale-up scheme amount to $160 \mathrm{~kW}$. This number is probably an overestimation, because losses are known to be relatively smaller in bigger plants. By this scheme the basic idea of how big the mass and heat flows in the semi-industrial plant should be is obtained. In the prediction $798 \mathrm{~kW}$ of dry gas is produced. Note that this value encompasses both heating up from $25^{\circ} \mathrm{C}$ to $850^{\circ} \mathrm{C}$ and the LCV of dry gas, see Eq. 1. A considerable amount of fuel oil must be fed to the riser (35. $2 \mathrm{~kg} / \mathrm{h}$ or $410.7 \mathrm{~kW}$ ), by which an efficiency of the plant is reduced, see also $E q$. 2. CGE amounts to $45 \%$. The low CGE values are caused by high losses and high steam-tofuel mass ratio. ${ }^{12}$ In the pilot plant experiment that was taken as a basis the steam-to-carbon mass ratio amounted to quite a high value of $2.3 \mathrm{~kg} / \mathrm{kg}$.

The first scale-up prediction is based on the experimental results and the dry gas contains hydrocarbons which heighten its LCV. There are two additional flows of tars and entrained char not shown in Fig. 3. A sum of both amounts to approximately $33 \mathrm{~kW}$ for a plant of $720 \mathrm{~kW}$ fuel power. A co-gasification process in semi-industrial plant would probably look like one in Fig. 3, were it not for the losses which are overestimated.

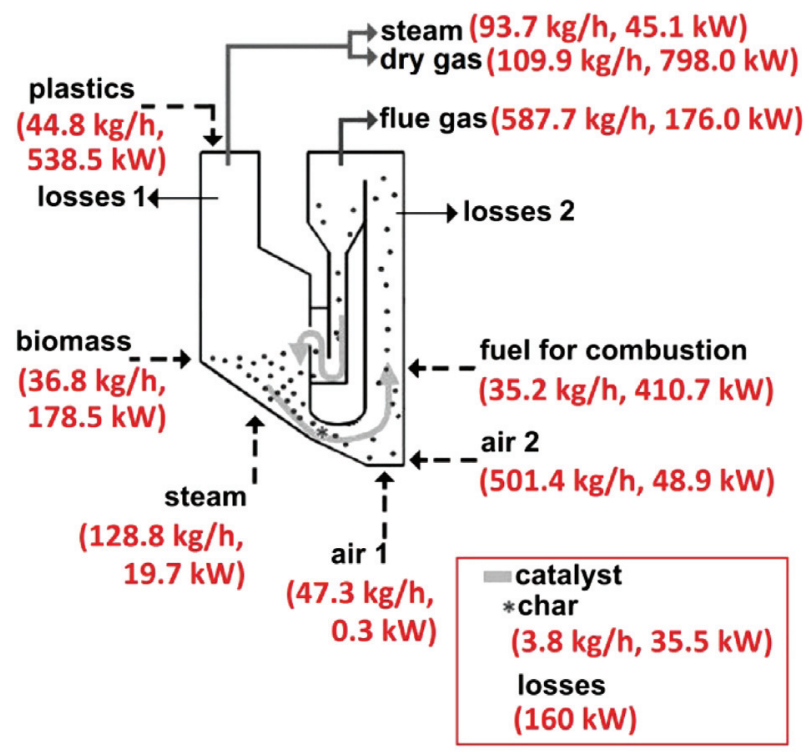

Fig. 3. Scale-up results obtained by taking pilot plant experiment as a basis. With $160 \mathrm{~kW}$ of losses the cold-gas efficiency amounts to $45 \%$.

The three further predictions are mathematically more sophisticated, as already described above in the section Modeling. The equilibrium model simulations are similar to the first prediction regarding the flows of air 1, air 2 , biomass, plastics and steam. These scaled-up flows can be found in Fig. 3, they apply to equilibrium model simulations as well.

However, the flows out of gasification reactor are subject to mathematical prediction. Product gas composition is restricted by WGS reaction. The losses are taken as a parameter which has a strong influence on the mass and heat flows out of the reactor, see Table 4.

Table 4. Dry gas compositions, mass and heat flows as predicted by equilibrium model. For the flows of air 1, air 2, plastics, biomass and steam to gasification reactor refer to Fig. 3 .

\begin{tabular}{lccc}
\hline & $\begin{array}{c}\text { Losses } \\
\text { of 160 kW }\end{array}$ & $\begin{array}{c}\text { Losses } \\
\text { of 115 kW }\end{array}$ & $\begin{array}{c}\text { Losses } \\
\text { of 70 kW }\end{array}$ \\
\hline$m_{\mathrm{C}}(\mathrm{kg} / \mathrm{h})$ & 26.3 & 12.8 & 0.1 \\
$m_{\mathrm{O}}(\mathrm{kg} / \mathrm{h})$ & 17.2 & 28.0 & 38.2 \\
$m_{\mathrm{DG}}(\mathrm{kg} / \mathrm{h})$ & 99.3 & 134.3 & 164.7 \\
$m_{\mathrm{SG}}(\mathrm{kg} / \mathrm{h})$ & 84.8 & 63.3 & 45.7 \\
$m_{\mathrm{FG}}(\mathrm{kg} / \mathrm{h})$ & 592.2 & 589.5 & 587.0 \\
$P_{\mathrm{C}}(\mathrm{kW})$ & 248.0 & 120.5 & 0.5 \\
$P_{\mathrm{O}}(\mathrm{kW})$ & 200.6 & 326.6 & 445.2 \\
$P_{\mathrm{DG}}(\mathrm{kW})$ & 613.6 & 792.9 & 962.4 \\
$P_{\mathrm{SG}}(\mathrm{kW})$ & 40.9 & 30.5 & 22.0 \\
$P_{\mathrm{FG}}(\mathrm{kW})$ & 171.9 & 174.4 & 176.7 \\
$\mathrm{CGE}(\%)$ & 48 & 54 & 59 \\
$\mathrm{y}_{\mathrm{H} 2}(\%$ vol., dry & 71.8 & 67.6 & 64.6 \\
$\mathrm{y}_{\mathrm{CO}}(\%$ vol., dry & 16.9 & 22.8 & 27.9 \\
$\mathrm{y}_{\mathrm{CO} 2}\left(\%{ }_{\text {vol., dry }}\right)$ & 11.3 & 9.6 & 7.5 \\
$\mathrm{LCV}_{\mathrm{dry} \text { gas }}\left(\mathrm{MJ} / \mathrm{Nm}^{3}\right)$ & 9.9 & 10.2 & 10.5 \\
\hline
\end{tabular}


The calculation shows that the assumption of $\lambda=1$ in the riser actually means the output of the riser remains fairly constant, approximately $320 \mathrm{~kW}$. Depending on the chosen value of losses, there remains $160-250 \mathrm{~kW}$ of heat available for endothermic reactions in the gasification reactor.

The result of this large variation can be seen in $T a b$ le 4: with high amount of heat available, i.e. when losses are low, feedstock is almost completely converted to gas, while the char and steam mass flows leaving the gasification reactor are low. To the contrary, lesser amount of heat for reactions, which corresponds to high losses, means that feedstock is transformed to char and steam remains largely unconverted. The mass flow of steam entering the gasification reactor is $128.8 \mathrm{~kg} / \mathrm{h}$ in all three cases, while the mass flow at the exit depends on the losses of the plant and was found to be $45.7 \mathrm{~kg} / \mathrm{h}$ for low losses and 84.8 $\mathrm{kg} / \mathrm{h}$ for high losses. The shift towards higher conversion when reducing the losses was actually expected, but the extent to which it happens is clearly seen on the example of steam. The losses were subject to variation in the equilibrium model, and by decreasing them the CGE value heightens considerably (see Table 4).

Reducing the losses of the DFB plant also influences the riser, where the assumption of $\lambda=1$ is applied. With reduced losses less of the char and steam exits the gasification reactor. In the riser the lack of char is compensated by adding more fuel oil. Surprisingly, this does not affect the CGE value in a negative way. The reason for this is that the amount and quality of dry gas is increasing when losses are reduced.

Above the effect of reducing the losses in the equilibrium model was described, and results obtained by applying three different values of losses were presented. It was found that with a reasonably chosen value of losses the prediction of results is possible. Other comparisons are however also meaningful and should be made. Firstly, the predictions can be compared to each other, i.e. the experiment-based scale-up can be compared to the equilibrium simulations. It is most meaningful to compare the two predictions which both have $160 \mathrm{~kW}$ of losses. Additionally, the results of experiment-based scale-up can be compared to other experimental results found in literature.${ }^{6,7}$ It is also of interest to compare equilibrium predictions to results of more complex equilibrium models, found in the literature. ${ }^{5,11}$

Comparison of experiment-based scale-up and the equilibrium prediction is easily made, because the flows to the gasification reactor are the same. When equilibrium model with $160 \mathrm{~kW}$ of losses is compared to linear scaleup of the experiment, the first conclusion is that more steam is converted in the equilibrium prediction. However, conversion of solids in the equilibrium simulation appears to be partial with $26.3 \mathrm{~kg} / \mathrm{h}$ of char leaving the reactor before being gasified. In case of experiment-based scale-up, the conversion of steam is lower, while the conver- sion of solids is high, only $3.8 \mathrm{~kg} / \mathrm{h}$ of char would not be gasified (see Fig. 3). The dry gas of experiment can be compared to equilibrium prediction: the hydrogen and carbon dioxide fractions are overpredicted, while the carbon monoxide content is underpredicted (see Table 2, Table 4). Similar trends have been observed by other researchers. ${ }^{5}$ Additionally, the methane amounts to $12.7 \%_{\text {vol,dry }}$ in experiment while the methane content was set to zero in the equilibrium scale-ups. The consumption of fuel oil also differs, mainly as a result of the char flow difference: the equilibrium scale-up requires $17.2 \mathrm{~kg} / \mathrm{h}$ of fuel oil, while in the linear scale-up little more than twice as much would be required for stable operation. Finally, there is small difference in CGE value: $45 \%$ for experiment-based scale-up and $48 \%$ for equilibrium prediction. In general, this comparison can also be used to show that exact prediction of the process with an equilibrium model is not possible.

The scale-up prediction that is based on the pilot plant experiment can be compared to other experimental results. The referential case for comparison is biomass mono-gasification in $100 \mathrm{~kW}$ pilot plant, because this is the feedstock for which the technology has been developed. Both experiments presented in this paper have been compared to biomass mono-gasification, see section 4.2 for co-gasification of biomass and plastics in pilot plant and section 4.3 for mono-gasification of biomass in semiindustrial plant. Many experiments with different feedstocks have been conducted in $100 \mathrm{~kW}$ pilot plant, encompassing the biomass mono-gasification, plastics mono-gasification as well as a co-gasification of plastics and biomass. ${ }^{5,6,7}$ From this literature data some conclusions can be drawn. In the co-gasification of biomass and plastics the following trends are found when comparing the experimental results: the changes occurring when the share of plastics feedstock is increased are non-linear ${ }^{6}$ in nature, the fractions of methane and lighter hydrocarbons in dry gas, LCV of dry gas and tar production increase. In the case of plastics mono-gasification the results differ considerably from those obtained with biomass mono-gasification, e.g. in PE mono-gasification the tar content in product gas was too high to be successfully measured by the usually applied tar assessment method. ${ }^{4}$ Additionally it was observed that in some cases ${ }^{7}$ of PE mono-gasification a high fraction of ethylene monomer occurs in the product gas. In general the results of co-gasification experiment presented in this paper are favourable, as already described above the low content of impurities and high content of hydrogen was achieved.

For the comparison of equilibrium models, the following should be emphasized: the number of reactions considered in the equilibrium calculation appears to influence the results. When only WGS reaction is taken in consideration, the methane content is not restricted by any equilibrium constraint. With addition of methane steam reforming reaction, the content of methane is restricted and in 
such cases it is calculated to be very close to zero. ${ }^{11}$ In literature both the models ${ }^{11}$ taking more reactions into account as well as WGS equilibrium models ${ }^{5}$ are found.

The results of equilibrium scale-ups can be compared to the mode ${ }^{11}$ that predict the equilibrium dry gas composition in gasification of wet biomass chips. It was calculated with a complex equilibrium model ${ }^{11}$ that the equilibrium methane content in raw gas is $0.1 \%$, while in scale-up predictions the methane content was assumed to be zero. In this point there is an agreement between the models. Additionally, predicted ${ }^{11}$ contents of dry gas were $56.2 \%_{\text {vol.dry }}$ for hydrogen, $31.2 \%_{\text {vol.dry }}$ for carbon monoxide and $12.4 \%_{\text {vol.dry }}$ for carbon dioxide. These results match well enough with the case of $70 \mathrm{~kW}$ losses from Table 4 . A complete match is not to be expected, because the losses are $5 \%$ in one case and approximately $10 \%$ in the other, while the feedstock composition entering the gasification reactor also differs.

Equilibrium scale-up simulations can also be compared to the WGS equilibrium predictions ${ }^{5}$ with high content of methane. Even though the feedstock used and the methane fractions in dry gas differ, the trends observed in both are similar: overprediction of carbon dioxide and hydrogen combined with underprediction of carbon monoxide. It appears that allowing the presence of methane and hydrocarbons in dry gas actually improves the WGS equilibrium predictions, since the overprediction of hydrogen fraction is relatively small. ${ }^{5}$ In case of scale-up predictions the methane fraction was however chosen to be zero, because this suits the theoretical nature of the equilibrium model.

The steady state predictions provide for general, crude image of what process could look like. It is known that the equilibrium is not achieved in the gasification experiments, and by reducing the losses the increase in conversion can only be expected when there is enough time for chemical reactions to proceed. Better predictions would probably be achieved by chemical kinetic models, which take the residence time of chemical species in account. As stated in the introduction, the aim of the current work was to predict the basic operating conditions of the plastics and biomass co-gasification in $750 \mathrm{~kW}$ semi-industrial plant. The data for process design was obtained from two major sources: (i) the successful co-gasification experiment in the $100 \mathrm{~kW}$ pilot plant and (ii) mathematical manipulation of the equilibrium model. The scale-up predictions represent usable contribution to the future operation of semi-industrial plant.

\section{Conclusions}

The results of experimental work (TGA, $100 \mathrm{~kW}$ pilot plant and $750 \mathrm{~kW}$ semi-industrial plant) paved the way to scale-up procedure: minimal residence time in the gasification reactor for the biomass and plastics co-gasification is approximately 5 minutes. Mass and heat flows for

continuous and efficient operation of the pilot plant are known. With scale-up the problem of losses appears-they are assumed to be between $70 \mathrm{~kW}$ and $160 \mathrm{~kW}$ in the semi-industrial plant of $750 \mathrm{~kW}$. With equilibrium model the effect of losses can be simulated, while the experiment-based prediction remains the most important.

\section{Acknowledgements}

The contribution of Slovenian Research Agency P0364 ARRS (financial support), Technical University of Vienna (experiments in the $100 \mathrm{~kW}$ pilot plant) and Bosio d.o.o. Celje (experiments in the $750 \mathrm{~kW}$ semi-industrial plant) is gratefully acknowledged.

\section{Notation}

$f$

$h$

$L C V$

$C G E$

$m$

$P$

$y$

\section{Greek letters}

$\lambda$

\section{Subscripts}

A1

A2

B

C

carbon

$\mathrm{CO}$

$\mathrm{CO} 2$

DG

FG

heat

hydrogen

$\mathrm{H} 2$

$\mathrm{H} 2 \mathrm{O}$

in

L

O

out

oxygen

$\mathrm{P}$

PG

$\mathrm{S}$

SG

total air-fuel equivalence ratio, /

air 1

air 2

biomass

char

carbon in elemental mass balance

carbon monoxide

carbon dioxide

dry gas

flue gas

heat balance

hydrogen in elemental mass balance

hydrogen

steam

in the gasification reactor

losses

fuel oil

out of gasification reactor

oxygen in elemental mass balance

plastics

product gas (both dry gas and steam)

steam to gasification reactor

steam in product gas

including mass and heat balances

measured temperature of the flow 


\section{References}

1. H. Hofbauer, M. Kaltschmitt, T. Nussbaumer, in: M. Kaltschmitt, H. Hartmann, H. Hofbauer (Ed.): Energie aus Biomasse $2^{\text {nd }}$ Edition, Springer, Heidelberg, Germany, 2009, pp. 375.

2. H. Hofbauer, A. Vogel, M. Kaltschmitt, in: M. Kaltschmitt, H. Hartmann, H. Hofbauer (Ed.): Energie aus Biomasse $2^{\text {nd }}$ Edition, Springer, Heidelberg, Germany, 2009, pp. 600 633.

3. T. Pröll, C. Aichernig, H. Hofbauer, R. Rauch, Proceedings of ASME Turbo Expo 2004: Power for Land, Sea, and Air, Vienna, Austria, 2004.

4. M. Narobe, J. Golob, D. Klinar, V. Francetič, B. Likozar, Bioresour. Technol. 2014, 162, 21-29.

http://dx.doi.org/10.1016/j.biortech.2014.03.121

5. V. Wilk, J.C. Schmid, H. Hofbauer, Biomass Bioenerg. 2013, 54, 46-58.

http://dx.doi.org/10.1016/j.biombioe.2013.03.018

6. V. Wilk, H. Hofbauer, Energ. Fuel. 2013, 27, 3261-3273. http://dx.doi.org/10.1021/ef400349

7. V. Wilk, H. Hofbauer, Fuel 2013, 107, 787-799. http://dx.doi.org/10.1016/j.fuel.2013.01.068

8. G. Löffler, S. Kaiser, K. Bosch, H. Hofbauer, Chem. Eng. Sci. 2003, 58, 4197-4213.

http://dx.doi.org/10.1016/S0009-2509(03)00232-X
9. T. Pröll, H. Hofbauer, Fuel Process. Technol. 2008, 89, 1207-1217. http://dx.doi.org/10.1016/j.fuproc.2008.05.020

10. S. Vyazovkin, N. Sbirrazzuoli, Macromol. Rapid Comm. 2006, 27, 1515-1532. http://dx.doi.org/10.1002/marc.200600404

11. G. Schuster, G. Löfller, K. Weigl, H. Hofbauer, Bioresour. Technol. 2001, 77, 71-79. http://dx.doi.org/10.1016/S0960-8524(00)00115-2

12. R. Rauch, Results of parameter tests, http://www.ficfb.at/pilot.htm, (assessed: September 24, 2014)

13. I. Plazl, M. Lakner, in: Uvod v modeliranje procesov, Založba FKKT, Ljubljana, Slovenia 2004, pp. 1-3.

14. M. Narobe, J. Golob, Proceedings of the $21^{\text {st }}$ European Biomass Conference and Exhibition, Copenhagen, Denmark, 2013.

15. M. Narobe, J. Golob, M. Sekavčnik, D. Perko, J. Mele, Proceedings of the 15th Austrian Chemistry Days, Graz, Austria, 2013.

16. R. Rauch, C. Pfeifer, K. Bosch, H. Hofbauer, D. Swierczynski, C. Courson, A. Kiennemann, Science in Thermal and Chemical Biomass Conversion, Victoria, Canada, 2004.

17. J. Mele, Catalytic Biomass Gasification In Fluidized Bed With Superheated Steam, Ph.D. dissertation, Ljubljana, Slovenia, 2014.

\section{Povzetek}

V 100 kW pilotnem uplinjevalniku z dvojnim lebdečim slojem (DFB) je bilo doseženo uspešno skupno uplinjanje plastike in biomase. Rezultati eksperimenta na pilotnem uplinjevalniku so bili uporabljeni kot dobra osnova za napoved procesa v $750 \mathrm{~kW}$ polindustrijskem DFB uplinjevalniku. Z osemkratnim povečanjem masnih in toplotnih tokov je nastala poenostavljena shema procesa skupnega uplinjanja obeh goriv. Izgube naj bi bile pri večjih uplinjevalnikih relativno manjše. Z ravnotežnim modelom je bil preučevan učinek zmanjševanja izgub. Predvidene so bile tri različne situacije $\mathrm{z}$ naslednjimi vrednostmi izgub: $70 \mathrm{~kW}, 115 \mathrm{~kW}$ in $160 \mathrm{~kW}$. Z ravnotežnim modelom je bilo ugotovljeno, da zmanjševanje izgub vodi do večje pretvorbe goriva. 